\title{
ГЛОБАЛЬНІ ТРЕНДИ МІЖНАРОДНИХ ВІДНОСИН
}

\author{
Коппель О. А., Пархомчук О. С.
}

\section{ВСТУП}

Проблематика глобальних трендів як найбільш кардинальних напрямів розвитку людства, фундаментальної та максимально тривалої традиції руху соціуму посідає важливе місце в сучасній науці. Це спроби осягнути глобальний розвиток та визначити характеристики часової ритміки глобальної системи в межах універсальних закономірностей, акцентування тих чи інших його рис та напрямів розвитку. Це, по суті, передбачає виявлення масштабних всесвітніх / глобальних закономірностей, які визначають кожний етап еволюції людства і формують сутність кожного етапу еволюції, визначаючи i глобальні тренди міжнародних відносин. У суспільних науках поступово прийшло усвідомлення того, що розв'язання глобальних проблем вимагає підвищення рівня керованості світовим розвитком.

\section{1. Теоретичні аспекти дослідження глобальних трендів міжнародних відносин}

Дослідження вказаної проблематики, зокрема глобальних трендів міжнародних відносин, характеризується недостатньою концептуальною, в тому числі категоріальною визначенністю, що пояснюється міждисциплінарним характером глобальних досліджень. У їх концептуалізації виокремимо два основних підходи. Перший з них представлений роботами філософів, соціологів, психологів, у яких акцентується увага на якісних трансформаціях світополітичної системи загалом. Другий підхід головну увагу зосереджує на фактологічному, прикладному аналізі глобальних трендів міжнародних відносин.

Сучасна світова політика характеризується якісно новим станом міжнародного середовища, в якому діють як традиційні суб'єкти міжнародних віносин - держави, так і нові суб'єкти. Саме тому характеристика стану середовища стає не менш важливою, ніж характеристика поведінки міжнародних акторів. Ці зміни найчастіше пов'язують з глобалізацією, а глобальний розвиток розглядається як середовище міжнародних відносин як системи взаємодій. 
Дослідження глобального розвитку та розвитку взаємовідносин між його складниками являє собою спроби побудови людською свідомістю абстрагованих моделей розвитку людства у просторі та часі. Але варто зазначити, що на цьому шляху виникають певні проблеми. По-перше, будь-яка аналітична модель як спеціально синтезований для зручності дослідника об'єкт, адекватний цілям дослідження, і як система, яка слугує засобом отримання інформації щодо іншої системи, невідворотно буде спрощувати наше розуміння дійсності. По-друге, для того щоб побудувати вказану модель, потрібна як теорія більш високого рівня, що перевищує можливості теоретичного апарату сучасних суспільних наук, так i вибір тієї чи іншої парадигми дослідження.

Таким чином, під глобальним розвитком розуміються закономірні якісні зміні у просторі та часі глобальної системи, які мають незворотний і спрямованний характер, тобто сукупність просторовочасових змін, що стосуються глобального суспільства. Отже, це розвиток людського суспільства як соціально-історичного феномену в єдності його внутрішніх якостей і всієї сукупності відносин і зв'язків, в тому числі і в міжнародному житті.

Природу та головні тенденції глобального розвитку характеризують глобальні тренди (соціальні, політичні, економічні, наукові, культурні) як основні напрями руху глобального суспільства, які визначають основні напрями еволюції сучасного світу і майбутне людства. Ці тренди мають глобальний характер, тобто охоплюють весь світ, впливаючи на життя світового співтовариства. В той же час вони розрізняються за масштабами поширення, тобто діють у різних частинах світу з різним ступенем та інтенсивністю. Відрізняються вони і за тривалістю існування, тобто строки їх дії обмежені і рано чи пізно їм на зміну приходять альтернативні тренди. Тісно взаємодіючи один з одним і доповнюючи один одного, вони здійснюють кумулятивний вплив на стан світу. Це крупномасштабні довгострокові процеси глобального розвитку, котрі визначають якісний зміст сучасного етапу еволюції світосистеми.

Особливого значення набуває виокремлення питань філософського характеру, методологічних аспектів дослідження глобальних трендів міжнародних відносин як стійких та довгострокових тенденцій їх розвитку, з'ясування, які саме тренди є глобальними та визначення специфіки прояву мегатрендів в міжнародно-політичній сфері. Варто враховувати такі характеристика трендів, як їх глобальний характер, поширення від центру до периферії, те, що регіональні та національні 
зміни є лише їх елементами, в різних зонах ці процеси, в яких синтезується циклічний та лінійний час, можуть набувати різної форми.

3 точки зору представників цивілізаційної теорії, зокрема I. Данілевського та О. Шпенглера, історія не розвивається лінійно, на відміну від окремих культурно-історичних спільнот (цивілізацій), тому визначення ії глобальних тенденцій виявляється неможливим ${ }^{1}$.

Другий підхід базувався на визнанні хвильового характеру політичних процесів і засновувався на концепції відцентрових та доцентрових тенденцій у розвитку соціальних спільнот (К. Ясперс, С. Хантінгтон). Так, зокрема, С. Хантінгтон висунув ідею хвильової природи світового розвитку ${ }^{2}$. Згідно 3 коваріантною теорією К. Ясперса, історичний час обмежений початком і кінцем і поділяється на чотири періоди: доісторія (передісторія); стародавні культури; осьовий час; технічний вік, а світова історія пов'язана з розвитком новоєвропейської науки і техніки та загальною інтеграцією людства ${ }^{3}$.

У межах третього підходу мегатренди - це діади процесівантагоністів, які змінюють один одного в певному циклічному ритмі: глобалізація - деглобалізація (ізоляціонізм); інтеграція - дезінтеграція (націоналізм); демократизація - дедемократизація (посилення авторитарних режимів) ${ }^{4}$.

Крім вже зазначених, до головних мегатрендів глобального розвитку, які визначають глобальні тренди міжнародних відносин, вважаємо за необхідне віднести стиснення історичного і політичного часу, що передбачає збільшення інтенсивності історичних подій у перерахунку на одиницю часу та зменшення тривалості історичних $\mathrm{i}$ політичних циклів. Вплив вказаного мегатренду на глобальні тренди міжнародних відносин полягає в тому, що вони набувають більш обмежений час дії, яка буде послаблюватись в умовах подальшої

${ }^{1}$ Данилевский Н.Я. Россия и Европа: Взгляд на культурные и политические отношения Славянского мира к Германо-Романскому. Санкт-Петербург, 1995. C. 59-61.

2 Hantington S. Democracy's Third Wave / S. Hantington. Journal of Democracy. 1991. Spring. P. 9-16.

3 Ясперс К. Смысл и назначение истории. Сравнительное изучение ичивилизаций: Хрестоматия : Учеб. пособие для студентов вузов / Сост., ред. и вступ. сл. Б.С. Ерасов. Москва, Аспект Пресс,1999. 556 с.

${ }^{4}$ Мегатренды мировой политики и их развитие в XX1 веке: учеб. пособие для студентов вузов. / Под ред. М.М. Лебедевой. Москва : Издательство «Аспект Пресс», 2019. 400с. С. 6. 
прискореної трансформації політичної системи світу, що неминуче призведе до появи нових трендів. Значний вплив на глобальні тренди міжнародних відносин мають такі мегатренди глобального розвитку, як збільшення темпів споживання, гіперспоживання; перехід до інформаційного суспільства на основі вироблення і споживання інформації; зростання ролі мережевих структур, зокрема у світовій політиці.

Джон Нейсбітт виступив популяризатором використання терміну «мегатренд». Він видає в 1982 році книгу «Мегатренди», в якій визначає найбільш кардинальні напрями розвитку суспільства ${ }^{5}$. Наступна книга Дж. Нейсбітта і П. Ебурдін«Мегатенденції, рік 2000. Десять нових напрямів 90-х років» вийшла друком у 1990 р.. .

Доходимо висновку, що необхідно розрізняти глобальні тренди розвитку суспільства як соціально-історичного феномену в єдності його внутрішніх якостей і всієї сукупності відносин і зв'язків у міжнародному житті, тобто так званий соціально-історичний розвиток; цивілізаційні процеси; глобальні тренди міжнародних відносин. Щодо останніх, то, як підкреслює Д. Лубківський у передмові до праці Р. Хааса «Розхитаний світ. Зовнішня політика Америки і криза старого ладу», у літературі про міжнародні відносини формується жанр «концептуального огляду головних міжнародних проблем», спроби «охопити і викласти стратегічну суть складних історичних і сучасних зовнішньополітичних процесів. Ідеться про особливе вміння бачити головне, не легковажаючи дрібницями, але й без надмірної

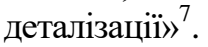

\section{2. Трансформація сучасної політичної організації світу}

У 1990-х рр. XX - на початку XXI століття відбувається низка структурних змін в міжнародних відносинах, які кардинальним чином вплинули на глобальні тренди міжнародних відносин. Загалом можна погодитись 3 поглядом, що на сучасному етапі відбувається трьохскладова трансформація сучасної політичної організації світу. Це трансформація Вестфальської світополітичної моделі, яку зумовлює глобалізація як мегатренд глобального розвитку, трансформація

${ }^{5}$ Naisbitt J. Megatrends. The New Directions Transforming Our Lives. N.Y. : Warner Books, 1982. C. 7-10.

${ }^{6}$ Нэсбитт Д. Эбурдин П. Что нас ждет в 90-е годы. Мегатенденции. Год 2000: десять новых направлений на 90-е годы. Пер. с англ. Москва, 1992.

7 Хаас Р. Розхитанний світ. Зовнішня політика Америки і криза старого ладу ; пер. 3 англ. М.М. Климчук. Київ : Основи, 2019. 376 с. С. 13. 
сучасної міжнародної системи, значним чином зумовлена інтеграцією як мегатрендом, і трансформація політичних систем окремих країн світу, зумовлена демократизацією 5 .

Трансформація Вестфальської світополітичної моделі і розпад Ялтинсько-Потсдамської системи примусили політиків та вчених будувати прогнози відносно майбутнього політичного світоустрою, які $\epsilon$ необхідними 3 позицій якісного управління глобальними трендами міжнародних відносин. Значний внесок у розвиток цього напряму внесла діяльність Римського клубу .

Ще у 1999 p. Національна розвідувальна рада США у співробітництві з Державним департаментом і Проектом прогнозу глобального майбутнього ЦРУ розпочала роботу над проектом «Глобальні тенденції 2015», організувавши два відкритих симпозіуми під загальною назвою «Варіанти глобального майбутнього: 20002015 рр.». У цьому прогнозі передбачалося, що держави залишаться основними гравцями на міжнародній арені, хоча роль недержавних акторів буде мати тенденцію до зростання. Буде зростати і кількість важливих гравців, що ставитиме під загрозу лідерство США. Це такі країни, як Китай, Росія, Індія, Мексика і Бразилія; регіональні організації, як ЄС; велика кількість ТНК і некомерційних організацій, що набирають вагу на міжнародній арені.

Автори доповіді запропонували чотири вірогідні сценарії розвитку людства до 2015 р.: «всеохопна глобалізація» за підвищення ефективності глобального та регіонального колективного управління; «згубна глобалізація» та посилення нерівномірності розвитку окремих країн та регіонів; «регіональна конкуренція» та посилення опору глобальній перевазі США у разі передачі повноважень глобальних організацій регіональним інститутам; «постполярний світ» із посилення політичної напруги у відносинах США з СС та суперництві між азійськими державами? .

У 2002 р. американські експерти опублікували збірку статей, в якій вибудовувались чотири можливих моделі міжнародної системи у

${ }^{5}$ Naisbitt J. Megatrends. The New Directions Transforming Our Lives. N.Y. : Warner Books, 1982. C. 7-10

8 Офіційний сайт Римського клубу. URL: http://www.clubofrome.org/eng/ home.

Global Trends Final Report. URL: http://www.g20-g8.com/g8g20/g20/english/for-the-press/news-releases/cannes-summit-final-

declaration.1557.html. 
XXI ст.: імперія, баланс сил, глобальна демократія та колективна безпека ${ }^{10}$.

«Проект-2020» «Контури світового майбутнього» щодо перспектив та глобальних тенденцій розвитку світу на першу чверть XXI ст. розпочався у 2003 р. Заключна доповідь під назвою «Контури світового майбутнього: Доповідь за Проектом-2020 Національної розвідувальної ради» була опублікована в серпні 2004 р. Цей довготерміновий прогноз окреслив ключові тенденції та сценарії розвитку людства до 2020 року. Він презентував імовірне унормування світового поступу за чотирма провідними сценаріями. Перший, 3 умовною назвою «Давоський світ», означав успішний поступ глобалізації, включення Китаю та Індії до кола провідних гравців, що надасть процесу глобалізації «незахідне обличчя». Другий сценарій під назвою "Рax Americana" пропонував бачення майбутнього з ключовою домінантою сучасності - США, які визначатимуть вибір моделей глобального розвитку. Третій сценарій - «Новий Халіфат» передбачав зростання викликів західній системі цінностей завдяки задіянню все більшої кількості населення та збільшення простору поширення нехристиянскої релігійної ідентичності, створення транснаціонального теократичного утворення, заснованого на релігійній свідомості, що мало загальмувати глобалізаційні процеси. За сценарієм «Кола жаху», значна частина світу стає простором насильства та нестабільності, географічно зафіксованими від Близького Сходу до Південно-Східної Азії, жодна організація, крім НАТО, де домінують США, не здатна буде взяти на себе відповідальність за підтримання балансу у світі. Піднесення КНР, Індії та деяких інших країн (Бразилія, Іран) як можливих глобальних гравців буде мати негативні наслідки, порівняні 3 піднесенням Німеччини наприкінці XIX століття ${ }^{11}$.

На думку авторів звіту «Майбутне у 2030 році», підготовленого громадською організацією «Вільна Всесвітня Академія» у 2005 р., світ у 2030 р. буде поділено на три регіони: глобалізований регіон $(51,5 \%$ населення) зі зростаючим середнім класом - Північна Америка, Океанія, Північно-Східна Азія, Індія, Східна Свропа, Південно-Східна Азія, Центральна Америка; відсталий регіон (34,5\% населення) під

${ }^{10}$ American power in the 21st century. David Held, Mathias Koenig-Archibugi. Google books. URL: http://books.google.ae/books.

Global Trends 2020: the world in 2020. URL: http://www.freeworldacademy.com/globalleader/trends . htm\#5. 
владою ісламізму - Близький Схід, Африка, Південна Азія та регіон, що занепадає, - (14\% населення світу $)^{12}$.

У листопаді 2008 р. Національна розвідувальна рада США оприлюднила доповідь на тему «Глобальні тенденції 2025: світ, що змінився〉 як чергову спробу виявити основні фактори та тенденції, які визначатимуть розвиток міжнародних відносин. У доповіді на цей раз констатувалось, що з підйомом Китаю, Індії та інших держав виникає глобальна багатополярна система, зростає роль недержавних акторів. США залишаться єдиним світовим лідером, проте їх могутність і домінування поступово ослабне.

Автори доповіді запропонували чотири вірогідні сценарії світового розвитку до 2025 р. Перший - «Світ без Заходу», за яким на світову арену виходять нові потужні держави, що кидає виклик стабільності існуючої системи міжнародних відносин i може призвести до глобальних конфліктів. Другий сценарій - «Жовтневий сюрприз»неочікуваний природний катаклізм, прискорення процесів зміни клімату. Відповідно до третього сценарію - «Скандал у БРІКС», виникає конфлікт між новими потужними державами, зокрема між Індією та Китаєм, внаслідок боротьби за ресурси. Четвертий сценарій «Політика не завжди локальна (формування глобального світу)» передбачав втрату державами своєї провідної ролі у формуванні світової політики, що має прискорити розвиток субрегіональних та транснаціональних утворень, а глобальні кліматичні ризики призведуть до того, що контроль за вирішенням цих питань переміщується 3 державного рівня на наддержавний ${ }^{13}$.

3 останніх прогнозів на особливу увагу заслуговує доповідь «Розриви та відволікаючи фактори - переосмислення безпеки на 2040 рік», яку було підготовлено за результатами семінару, організованого РЕНД Корпорейшн у 2018 році. Дев'ятнадцять учасників семінару - представників широкого спектру галузей знань та професій, проаналізували безперервність та розриви від попередньої епохи та ймовірно очікувані або наслідкові зміни в найближчі 25 років. Неперервними вони визнавали ті тенденції та події, які були передбачувані, навіть якщо вони відбувалися прискореними темпами.

12 Global Trends 2030: the world in 2030. URK: http://www.freeworldacademy.com/globalleader/trends . htm\#5 nds. htm\#5.

13 Global Trends Final Report. URL: http://www.g20-g8.com/g8g20/g20/english/for-the-press/news-releases/cannes-summit-final-

declaration.1557.html. 
Головною метою цього звіту визначалось передбачення вирішальних проблем у сфері безпеки в світі до 2040 року, враховуючи наслідки політичних, технологічних, соціальних та демографічних тенденцій, які формуватимуть проблеми в галузі безпеки в найближчі десятиліття. 3 метою отримання достовірного уявлення про те, як світ може наслідувати або нехтувати прогнозами між теперішнім та 2040 роком, дослідники RAND проаналізували три попередні 25-річні періоди історії США. Учасники проаналізували та визначили пріоритетні напрями динаміки безперервності та розривів трьох попередніх періодів історії (1910-1935 pp., 1950-1975 pp., та 1990-2015 pр.) та обговорили широкий спектр можливих сценаріїв на 2015-2040 роки.

Для кожного періоду дослідники відслідковували події, які являли собою продовження попередніх тенденцій; вони суттєво не дивували, навіть якщо вони відбувалися прискореними темпами. Події, які розглядалися як передбачувані (відомі в літературі як «білі лебеді») підпадали під категорію неперервності (нерозривності). Дослідники також визначили «чорних лебедів» - події, які вважалися неможливими та непередбачуваними. Для періоду 1910-1935 pp. (визначеного як період «ядра, з якого може вирости сила») це непередбачувані обставини, пов'язані з Першою світовою війною, російською революцією та Великою депресією. Другий період - 19501975 рр. отримав назву періоду, коли «жоден куточок землі не може бути ізольованим». До непередбачуваних подій відносили випробування СРСР атомної бомби в 1947 р., запуск супутника у 1957 році, швидку деколонізацію, війни в Кореї та В'єтнамі та нафтове ембарго 1973 року. В період з 1990 по 2015 рр. - період, коли «для здивування не вистачає часу» розпадається Радянський Союз, Росія та Китай лібералізують свою економіку. Інші події включають терористичні напади 11 вересня, фінансові кризи 2008 р., анексію Криму Росією, Маастрихтський договір 1992 р. про створення Європейського Союзу та зниження світової бідності. «Здивування» стає ключовим словом для періоду, який приніс крах Радянського Союзу, розширення Організації Північноатлантичного договору (НАТО), теракти 11 вересня 2001 р., посилення участі США в Афганістані та Близькому Сході, винахід Інтернету, підйом Китаю та обрання першого афро-американського президента США. В 20152040 рр. (період «винаходження майбутнього») до прогнозованих змін віднесено кліматичні, які йдуть на користь деяким країнам, але шкодять іншим, змінюючи баланс сил. Відрізняє цей період від 
попередніх стрімка поява більш потужних інструментів спостереження, аналізу та навчання.

На основі обговорень на семінарі та подальшого аналізу у звіті визначено п'ять можливих сфер для подальших досліджень RAND: (1) прогнозування очікуваних та непередбачуваних подій у сфері зайнятості, (2) управління внутрішньою та міжнародною міграцією там, де це $є$ необхідним, (3) наслідки старіння населення Росії та Китаю, (4) впевненість у невизначеності та (5) наступні докорінні зміни у військовій справі. До здобутків вказаної доповіді слід віднести запропоновану схему для подальшого аналізу виникаючих проблем світового порядку. Один з учасників конференції процитував старий афоризм «Найкращий спосіб передбачити майбутнє - це вигадати його», щоб нагадати іншим учасникам, що деякі прогнозовані або непрогнозовані події $\epsilon$ антропогенними. Доки ми не побачимо розвиток штучного інтелекту, який буде перевищувати людські можливості (Вернор Вінге назвав цей момент «сингулярність» - точка, після якої світ виходить за межі нашої здатності зрозуміти це), далекосяжні сценарії підлягатимуть людським зусиллям, принаймні певною мірою. ${ }^{14}$

Погоджуючись 3 поглядом, що за останні роки ключовим глобальним трендом міжнародних відносин стало послаблення безпеки людства, зазначимо, що ця проблема опинилась у центрі уваги світового співтовариства не тільки внаслідок розпаду біполярної системи, оскільки механізми забезпечення міжнародного порядку мали багато в чому спадкоємний характер, а внаслідок спроб Російської Федерації переглянути своє місце в сучасній міжнародній системі. той же час перші ознаки ідеологічного обгрунтування аналогічних спроб стають помітними ще наприкінці XX - на початку XXI століття, хоча спочатку вони виглядали скоріше як інтелектуальний виклик стратегічному курсу розвитку РФ того періоду. В цьому плані на особливу увагу заслуговують аналогічні прогнози російських дослідників, спроби визначити головні тренди міжнародних відносин та місце Росії в сучасному світі ${ }^{15}$. Робота «Світ навколо Росії: 2017.

${ }^{14}$ Discontinuities and Distractions-Rethinking Security for the Year 2040 / Findings from a RAND Corporation Workshop/ Andrew R. Hoehn, Andrew Parasiliti, Sonni Efron, Steven Strongin. Santa Monica, California, 2018. 19 p.

15 Бажанов Е.П., Бажанова Н.Е. Куда идет человечество? О тенденциях международных отношений в XXI веке = Where is Mankind Headed? Trends in International Relations in the XXI Century. Москва : Восток-Запад, 2009. 95 с.; Дроздов Ю.И., Илларионов С.И. Россия и мир. Куда держим курс? Москва : 
Контури недалекого майбутнього» побачила світ у 2007 p. ${ }^{16}$, більш довгостроковий прогноз того ж колективу авторів на чолі 3 С.А. Карагановим «Росія і світ. Нова епоха. 12 років, які можуть все змінити» - в 2008 р. ${ }^{17}$ Прогнозувалось, що поява нових центрів сили незворотньо призведе до часткового перерозподілу владної ієрархії і змін у системі прийняття рішень у світовій політиці та економіці, чому будуть активно протистояти «старі» центри сили ${ }^{18}$.

Активізація політики РФ на міжнародній арені знаходить концептуальне обгрунтування в серії праць, присвячених визначенню перспектив розвитку сучасного світу. В 2001 році в Росії було опубліковано працю під редакцією М.В. Ільїна на В.Л. Іноземцева «Мегатренди світового розвитку», в 2013 році - підручник «Мегатренди. Основні траекторії еволюції світового порядку в XXI столітті» під редакцією Т.А. Шаклеіної та А.А. Байкова, в 2019 році - підручник «Мегатренди світової політики та їх розвиток в XXІ столітті» під редакцією М.М. Лебедевої 19 .

Отже, у всіх прогнозах, незважаючи на наявні розбіжності в підходах та оцінках, світ майбутнього мав певні спільні характеристики, найголовніша з яких полягала в його глобалізованості, альтернатива глобалізації не розглядається або розглядається як катастрофа. Водночас у багатьох із них констатується, що Захід втрачає монополію на процеси глобалізації.

Артстиль-полиграфия, 2009. 351 с.; Лебедева М.М. Формирование политической структуры мира и место России в ней. Мегатренды мирового развития. Москва : Центр исслед. постиндустриального о-ва, 2001. С. 1-13; Лихачев В.Н. Современные проблемы мироуправления: российский подход. Москва : Вече, 2009. 399 с. Неклесса А. quodro Ordo современного мира. Мегатренды мирового развития. URL: http://www.knogg.net/2001_009.htm.; Примаков Е.М. Мир без России? К чему ведет политическая близорукость. Москва : Рос. газета, 2009. 239 с. ; Россия в изменяющемся мире / Ин-т стратегических оценок и анализа ; под ред. В.А. Гусейнова. Москва : Красная звезда, 2008. $167 \mathrm{c}$.

16 Мир вокруг России: 2017. Контуры недалекого будущего / под ред. А.С. Караганова. Москва : Культурная революция, 2007. 160 с.

${ }^{17}$ Россия и мир. Новая эпоха. 12 лет, которые могут все изменить / отв.ред. и рук. авт. кол. С.А. Караганов. Москва : АСТ ; Русь-Олимп, 2008. 444 с.

${ }_{18}$ Россия и мир. Новая эпоха. 12 лет, которые могут все изменить / отв.ред. и рук. авт. кол. С.А. Караганов. Москва : АСТ; Русь-Олимп, 2008. 444 с.

${ }^{19}$ Naisbitt J. Megatrends. The New Directions Transforming Our Lives. N.Y. : Warner Books, 1982. C. 7-10. 
Зміни в конфігурації міжнародної системи зумовили значну ступінь невизначеності в прогнозуванні процесів, які в ній відбуваються, а 3 іншого боку, стали поштовхом до теоретичних дискусій та розробки цілої низки нових концепцій. На відміну від вже згадуваного нами афорізму «найкращий спосіб передбачити майбутнє - це вигадати його», нагадаємо інший, який належить Д. Нейсбітту «найнадійніший спосіб передбачити майбутнє - зрозуміти теперішнє». Головні проблеми, які опинились у центрі уваги наукового співтовариства - це характер сучасної міжнародної системи, що передбачало дослідження параметрів полярності, лідерства, нової системи міжнародної стратифікації іï акторів, структури і середовища міжнародної взаємодії, процесів зміни (динаміки) цих станів, регулювання та саморегулювання цих процесів, формування нового світового порядку, трансформації політичної організації світу, тобто модифікації Вестфальської світополітичної моделі, зміни ролі держави та її основного атрибуту - суверенітету.

Після закінчення блокового протистояння виникає ідея щодо безконфліктного розвитку міжнародних відносин і переходу ліберальної демократії на домінуючі позиції в світі (Ф. Фукуяма). ${ }^{20}$ 3 іншого боку, С. Хантінгтон вказує на те, що по закінченню холодної війни замість блокового протистояння на перший план вийшли відмінності цивілізаційного характеру, що дає серйозні підстави до зіткнення інтересів держав. ${ }^{21}$ Принципово новими ознаками сучасної системи світу стали відсутність балансу сил та складність або навіть неможливість його відтворення, суверенізація особистості і закономірне підвищення іiі ролі в світових справах, різке якісне та кількісне зростання транснаціональних акторів. Основними елементами нестабільності в цій ситуації стає відсутність теоретичної ідеї, що виконувала б роль регулятора міжнародного порядку, несумісність старих та нових принципів регулювання міжнародного порядку, зокрема протиріччя між принципом невтручання у внутрішні справи i сучасні вимоги відносно захисту прав людини, які порушуються з боку власної держави, паралельне існування старих та нових інститутів, що посилює відчуття анархії і безладу міжнародної системи, переплетіння різних трактувань суверенітету без їх чіткої ієрархізації.

${ }^{20}$ Fukuyama F. The End of History. The National Interest. 1989. N 16. P. 3-18.

${ }^{21}$ Хантингтон С. Столкновение цивилизаций ; пер. с англ. Т. Велимеева, Ю. Новикова. Москва : ООО «Издательство АСТ», 2003. 603 с. 
Значною частиною дослідників (I. Валлерстайн, Ч. Капчан, П. Кеннеді, Н. Хомскі та інші) констатується тенденція до того, що могутність США хилиться до занепаду. ${ }^{22}$ В той же час неоконсерватори (П. Вулфовіц, Ф. Фукуяма) навпаки, не мали жодних сумнівів у тому, що США збережуть могутність, насамперед військову ${ }^{23}$. Неоліберали (Дж. Най-молодший, Р. Кеохейн) вважали, що США володіють потенціалом, необхідним для збереження своїх позицій i в майбутньому, за умови продуманої збалансованої та далекоглядної зовнішньополітичної стратегії ${ }^{24}$.

На підставі аналізу численних спроб визначення головних трендів сучасних міжнародних відносин доходимо висновку, що існує певний консенсус щодо визначення трьох найголовніших з них: глобалізація, інтеграція і демократизація. При цьому акцентується увага на тому, що глобальні тренди мають циклічно-хвильовий характер, розвиваються нерівномірно та нелінійно, а їх переплетіння породжує нову якість.

Основними елементами нестабільності виступають негативні наслідки глобалізації: нерівномірний розподіл переваг в процесі глобалізації світової економіки, погана керованість процесів глобалізації, поляризація в межах окремих країн та регіонів (глобальна асиметрія сучасного світу), загроза конфліктів на глобальному, регіональному, національному рівнях, загроза для деяких держав переходу контролю над їх економікою від національних урядів до більш потужних держав або транснаціональних корпорацій. Неоліберальна модель глобалізації сприяє консервації негативних моментів у світовій економіці. Вона призводить до регіоналізації або

22 Капчан Ч. Автономное управление: американская политика после «продвижения демократии» / Ч. Капчан, А. Маунт. Россия в глобальной политике. 2009. Т. 7. № 3. С. 52-68.

23 Fukuyama F. America at the Crossroads: Democracy, Power and Neoconservative legacy, New Haven / F. Fukuyama. Yale Yale University Press, 2006. 244 p.

24 Keohane R.N., J.-N. Y. Nye. Power and Independence, Westly Longman, 2001. 213 p.; Keohane R.O., Nye J. Jr. Governance in a Globalizing World / R. O. Keohane, N.Y.; J.S. Jr. Nye, Donahue (ed). Broukings Press, 2000. 386 p.; Nye J. What New World Order? Foreign Affairs. 1994. P. 83-96; Nye J. The Paradox of American Power: why the World's only Superpower can't it go alone. Oxford University Press, 2002. 240 p.; Nye J. Jr. Transformational Leadership and U.S. Grand Strategy. Foreign Affairs. 2006. July/August. $\mathrm{N} 4$. URL: http://www.foreignaffairs.com/article/61740/joseph-nye-jr/transformationalleadership-and-us-grande-strategy American power in the 21st century; David Held, Mathias Koenig-Archibugi. Google books. URL: http://books.google.ae/books. 
фрагментації, тобто посилення соціально-політичної гетерогенності світу на фоні вестернізаційного тиску з боку Заходу. Спостерігаються спроби різних країн та народів відгородити себе від негативних наслідків глобалізації шляхом пошуку специфіки свого регіону, своєї ідентичності. Тому головне завдання, 3 яким зіткнувся світ, - це забезпечення позитивного змісту глобалізації, перетворення глобалізації на позитивний чинник для всіх народів світу, для чого вона повинна базуватись на принципах справедливості, рівності i солідарності. Глобалізація 2.0 має відрізнятись від попередньої. Виникає новий світовий порядок, коли економічна влада переміщується в Азію, зростає просторове охоплення і щільність глобальних взаємозв'язків, ускладнюється їх структура, зростає ступінь взаємозалежності країн та народів.

Ідея щодо внутрішньої неоднорідності сучасної міжнародної системи i типологічної різнорідності іï підсистем знайшла відображення, зокрема у Г. Кіссінджера. Якщо в своїй роботі «Дипломатія» він висловлює точку зору, що порядок у сучасній системі буде забезпечуватись за зразком Віденського «концерту націй», але баланс сил буде здійснюватись на глобальному рівні, то в подальших працях, зокрема «Чи потрібна Америці зовнішня політика?» ${ }^{25}$ та «Світовий порядок» ${ }^{26}$, він вже акцентує увагу на неоднорідності глобальної міжнародної системи.

Таким чином, посилення елементів хаотичності в умовах глобалізації має негативні наслідки для сучасної міжнародної системи. Світ опинився перед новими ризиками, які мають не тактичний, а системний характер, стали наслідком системних змін у міжнародних відносинах. Структурні зміни в міжнародних відносинах супроводжуються трансформацією старих та виникненням нових загроз міжнародному порядку, кардинальним чином впливаючи на зміни середовища сучасної міжнародної системи. Міжнародні процеси все більш визначаються хаотичною взаємодією гравців різної природи- від держав до транснаціональних акторів та окремих індивідів. У процесі їх аналізу необхідно враховувати зміну політичної структури світу, кризу інституту глобального лідерства, переміщення центру світового розвитку, інверсію фундаментальних цінностей. Одним з головних сучасних глобальних трендів міжнародних відносин

${ }^{25}$ Kissinger H. Does America need a foreign policy?: Toward a diplomacy for the 21st century. New York: Simon \& Schuster, 2001. 352 p.

${ }^{26}$ Kissinger H. 'World Order'. Penguin Press, New York : 2014. 452 p. 
$\epsilon$ зниження ступеня захищеності людства, що потребує формування нового світового порядку, решта мегатрендів, зокрема зміна політичної структури світу, переміщення центру світового розвитку, інверсія фундаментальних цінностей похідні за функціональною приналежністю до нього. Визначальним для існування і розвитку міжнародної системи та її складників є той міжнародний порядок, який вибудовує ієрархію відносин між провідними державами.

\section{ВИСНОВКИ}

3 одного боку, визнаючи певний волюнтаризм та відсутність консенсусу дослідників у виокремленні глобальних трендів міжнародних відносин, акцентування уваги лише на ті чи інші аспекти явища, що досліджується, зробимо спробу їх узагальнення. Це трансформація міжнародних відносин у відносини світополітичні, що передбачає зміну параметрів Вестфальської системи, якісні та кількісні зміни учасників міжнародних відносин, трансформацію ролі держави i зростання значення недержавних акторів; посилення взаємозалежності, формування взаємозалежного світу, взаємодії в межах якого набувають системного характеру; розмивання національних кордонів і ерозія суверенітету; зміна політичної структури світу; зростання ролі мережевих структур у світовій політиці; ідеологізація міжнародних відносин, зростання ролі релігійного та цивілізаційного чинника; криза інституту глобального лідерства; переміщення центру світового розвитку (орієнталізація); універсалізація міграційних потоків; інверсія фундаментальних цінностей; віртуалізація суспільно-політичних відносин; нова модель зміни політичної влади і управління в окремих країнах; посилення глобальних проблем та зниження ступеня захищеності людства. Їх аналіз передбачає врахування взаємопов'язаності глобальних, регіональних та державних процесів, зокрема це прослідковується на прикладі таких глобальних трендів, як нова модель зміни політичної влади і управління в окремих країнах та трансформація політичних систем окремих країн світу.

Формування сучасного міжнародного порядку відбувається як діалектичний процес взаємодії тенденцій збереження наступальності 3 попередньою історичною формою існування міжнародного порядку і його радикального оновлення в найбільш істотних рисах. Він формується як порядок глобальної спільноти, як глобальний порядок, на основі поєднання як загальнолюдських, так i унікальних характеристик, які історично формувались на основі матеріальних та духовних цінностей традиційних культур та інтегративної культури 
світового співтовариства і потребують подальшого наукового дослідження.

Аналіз глобальних трендів міжнародних відносин дозволяє зробити висновки щодо доцільності використання категорії глобальних трендів в міжнародно-політичному аналізі.

Констатуємо і актуальність для України боротьби з так званими негативними трендами, які необхідно компенсувати за рахунок власних геополітичних переваг.

\section{АНОТАЦІЯ}

Аналізуються глобальні тренди міжнародних відносин як найважливішої гносеологічної, теоретичної та методологічної проблеми міжнародно-політичної науки. Визначено, що розвиток науки про міжнародні відносини свідчить про зростання значення та важливості іiі гносеологічного складника. Протягом всієї історії людства міжнародна система переходила від стану стабільності до стану нестабільності, від війни до миру. 3 метою визначення характеру суперечливих факторів, які впливають на міжнародну систему, досліджуються глобальні тренди міжнародних відносин в контексті глобального розвитку. Особливу увагу приділено теоретичним засадам дослідження політичних проблем і мегатрендів глобального розвитку. Виокремлено та проаналізовано наступні глобальні тренди міжнародних відносин: трансформація міжнародних відносин у відносини світополітичні, що передбачає зміну параметрів Вестфальської системи, якісні та кількісні зміни учасників міжнародних відносин, трансформацію ролі держави i зростання значення недержавних акторів; посилення взаємозалежності, формування взаємозалежного світу, взаємодії в межах якого набувають системного характеру; розмивання національних кордонів і ерозія суверенітету; зміна політичної структури світу; зростання ролі мережевих структур у світовій політиці; ідеологізація міжнародних відносин, зростання ролі релігійного та цивілізаційного чинника; криза інституту глобального лідерства; переміщення центру світового розвитку; універсалізація міграційних потоків; інверсія фундаментальних цінностей; віртуалізація суспільно-політичних відносин; нова модель зміни політичної влади і управління в окремих країнах; посилення глобальних проблем та зниження ступеня захищеності людства.

Доведено, що глобальна система знаходиться у стані радикальної трансформації, яка викликана дією суперечливих чинників, як 
внутрішніх, так і зовнішніх. Визначені особливості, глобальні тренди і тенденції формування нового світового порядку. Особлива увага приділяється важливій науковій проблемі організації сучасної міжнародної системи, ієрархії іiї елементів і кореляції між ними в процесі формування нового міжнародного порядку. Незважаючи на те, що кожна держава прагне до формування такої системи, яка найбільше відповідає іiі інтересам, тільки спільними зусиллями можливо досягнення бажаних результатів. Особлива увага приділяється основним особливостям і трендам формування нового світового порядку (НСП).

\section{ЛIТЕРАТУРА}

1. Данилевский Н.Я. Россия и Европа: Взгляд на культурные и политические отношения Славянского мира к ГерманоРоманскому.СПб,1995. С. 59-61.

2. Hantington S. Democracy's Third Wave / S. Hantington // Journal of Democracy. 1991. Spring. P. 9-16.

3. Ясперс К. Смысл и назначение истории. Сравнительное изучение цивилизаций: Хрестоматия: Учеб. пособие для студентов вузов / Сост., ред. и вступ. сл. Б.С. Ерасов. Москва, Аспект Пресс, 1999. $556 \mathrm{c}$.

4. Мегатренды мировой политики и их развитие в XX1 веке: учеб. пособие для студентов вузов. / Под ред. М.М. Лебедевой. Москва : Издательство «Аспект Пресс», 2019. 400с. С.6

5. Naisbitt J. Megatrends. The New Directions Transforming Our Lives. N.Y. : Warner Books, 1982. C. 7-10.

6. Нэсбитт Д. Эбурдин П. Что нас ждет в 90-е годы. Мегатенденции. Год 2000: десять новых направлений на 90-е годы. Пер. с англ. Москва, 1992.

7. Хаас Р. Розхитанний світ. Зовнішня політика Америки і криза старого ладу / Р. Хаас ; пер. 3 англ. М.М. Климчук. Київ : Основи, 2019. 376 c. C. 13.

8. Офіційний сайт Римського клубу. URL: http://www.clubofrome.org/eng/home.

9. Global Trends Final Report. URL: http://www.g20-g8.com/g8g20/g20/english/for-the-press/news-releases/cannes-summit-finaldeclaration.1557.html.

10. American power in the 21st century. David Held, Mathias KoenigArchibugi. URL: http://books.google.ae/books. 
11. Global Trends 2020: the world in 2020. URL: http://www.freeworldacademy.com/globalleader/trends. htm\#5.

12. Global Trends 2030: the world in 2030. URL: http://www.freeworldacademy.com/globalleader/trends . htm\#5 nds. htm\#5.

13. Global Trends Final Report. URL: http://www.g20-g8.com/g8g20/g20/english/for-the-press/news-releases/cannes-summit-finaldeclaration.1557.html.

14. Discontinuities and Distractions-Rethinking Security for the Year 2040 /Findings from a RAND Corporation Workshop/ Andrew R. Hoehn, Andrew Parasiliti, Sonni Efron, Steven Strongin. Santa Monica, California, 2018. 19 p.

15. Бажанов Е.П. Куда идет человечество? О тенденциях международных отношений в XXI веке = Where is Mankind Headed? Trends in International Relations in the XXI Century / Е.П. Бажанов, Н.Е. Бажанова. Москва : Восток-Запад, 2009. 95 с.; Дроздов Ю.И., Илларионов С.И. Россия и мир. Куда держим курс? Москва : Артстильполиграфия, 2009. 351 с.; Лебедева М.М. Формирование политической структуры мира и место России в ней. Мегатренды мирового развития. Москва : Центр исслед. постиндустриального о-ва, 2001. С. 1-13. Лихачев В.Н. Современные проблемы мироуправления: российский подход. Москва : Вече, 2009. 399 с. Неклесса A. quodro Ordo современного мира. Мегатренды мирового развития. URL: http://www.knogg.net/2001_009.htm; Примаков E.М. Мир без России? К чему ведет политическая близорукость. Москва : Рос. газета, 2009. 239 с. Россия в изменяющемся мире / Ин-т стратегических оценок и анализа ; под ред. В.А. Гусейнова. Москва : Красная звезда, 2008. 167 с.

16. Мир вокруг России: 2017. Контуры недалекого будущего / под ред. А.С. Караганова. Москва : Культурная революция, 2007. 160 с.

17. Россия и мир. Новая эпоха. 12 лет, которые могут все изменить / отв.ред. и рук. авт. кол. С.А. Караганов. Москва; АСТ; Русь-Олимп, 2008. $444 \mathrm{c}$.

18. Fukuyama F. The End of History. The National Interest. 1989. N 16. P. 3-18.

19. Хантингтон С. Столкновение цивилизаций ; пер. с англ. Т. Велимеева, Ю. Новикова. Москва : ООО «Издательство АСТ», 2003. $603 \mathrm{c}$.

20. Капчан Ч., Маунт А. Автономное управление: американская политика после «продвижения демократии». Россия в глобальной политике. 2009. Т. 7. № 3. С. 52-68. 
21. Fukuyama F. America at the Crossroads: Democracy, Power and Neoconservative legacy, New Haven. Yale Yale University Press, 2006. $244 \mathrm{p}$.

22. Keohane R.N. Power and Independence, J.-N. Y. Nye. Westly Longman, 2001. 213 p. Keohane R. O. Governance in a Globalizing World / R. O. Keohane, J. Jr Nye. N.Y., J.S. Jr. Nye, Donahue (ed). Broukings Press, 2000. 386 p.; Nye J. What New World Order? Foreign Affairs. 1994. P. 83-96; Nye J. The Paradox of American Power: why the World's only Superpower can't it go alone. Oxford University Press, 2002. 240 p.Nye J. Jr. Transformational Leadership and U.S. Grand Strategy J. Nye Jr. Foreign Affairs. 2006.July/August. N 4. URL: http://www.foreignaffairs.com/article/61740/joseph-nye$\mathrm{jr} /$ transformational-leadership-and-us-grande-strategy American power in the 21st century; David Held, Mathias Koenig-Archibugi. Google books. URL: http://books.google.ae/books.

23. Kissinger $H$. Does America need a foreign policy?: Toward a diplomacy for the 21st century. New York : Simon \& Schuster, 2001. 352 p.

24. Kissinger H. "World Order". Penguin Press, New York, 2014. 452 p.

\section{Information about authors: Koppel O. A.,}

Doctor of Historical Sciences, Professor, Professor at the Department of International Relations and Foreign Policy Institite of International Relations of Taras Shevchenko National University of Kyiv 36/1, Yu. Ilenko str., Kyiv, Ukraine

Parkhomchuk O. S., Doctor of Political Sciences, Professor, Professor at the Department of International Relations and Foreign Policy Institite of International Relations of Taras Shevchenko National University of Kyiv 36/1, Yu. Ilenko str., Kyiv, Ukraine 